\title{
Impact of Political Connections and Shari'ah Compliance on Firms' Profitability-A Case Study of Malaysia
}

\author{
Irum Saba, Mohamed Ariff Abdul Kareem, Mohamed Eskandar Shah Mohd Rasid, \\ INCEIF, Malaysia
}

\begin{abstract}
Connections between politicians and business houses are not uncommon. Literature shows that firms tends to connect with politicians/political parties to get easy access to credit, to have lax regulatory oversight, to have preferential treatment for the government contracts and for having access to insider information. On the other hand a Shari'ah compliant firm is considered to perform ethically and justly due to adherence to the rules and regulations prescribed by Shari'ah. In recent years the research on political connections of Malaysian listed firms is increased. But the comparison of politically connected listed firms and Shari'ah compliant listed firms in Malaysia is lacking. Malaysia is a leading country in Islamic finance hence; this paper analyzes the impact of political connections and Shari'ah compliance on the profitability of the listed firms' in Malaysia for the period of 2000-2014. The paper used regression technique for the analysis. The result of the study shows that Shari'ah compliant firms perform better than the politically connected firms. Shari'ah compliance has positive and significant impact on the profitability of the firm whereas political connections have negative and significant impact on the profitability of the firm in the case of Malaysia.
\end{abstract}

Key Words: Shari'ah, Political Connections, Performance, Malaysia

\section{Introduction}

In Malaysia, one coalition party, Barisan Nasional (BN) has been ruling the country since independence and is considered a strong party in the politics and business of Malaysia. General elections in Malaysia have been calm since 1957 till early 1990s. The political turbulence in Malaysia started in the 1990s when the overwhelming power of the coalition party began to decrease, which impacted the politically connected firms' performance. Despite the political turbulence, Prime Minister Najib's coalition party won the general elections May 2013 by a narrow margin. So far, Malaysia has had 6 prime ministers from the same party (Appendix 1) and each of them has tried to leave a legacy of his own.

The Government of Malaysia is focusing on economic growth and hence launched a program named Government-Linked Companies Transformation (GLCT) Program in May 2004. Five Government Linked Investment Companies (GLIC) namely Employee Provident Fund (EPF), Khazanah Nasional Berhad (Khazanah), Lembaga Tabung Angkatan Tentera (LTAT), Lembaga Tabung Haji (LTH) and Permodalan Nasional Berhad (PNB) are part of it. Government-linked companies (GLCs) are defined as companies that have a primary commercial objective and are under the control of a GLIC. The list of GLCs comprised of 20 companies but currently stands at 17 due to various mergers, demergers and other corporate exercises over the year (Appendix 2) (Putrajaya Committee, 2014). Despite the various steps taken by the current government as mentioned above, former Prime Minister Tun Dr. Mahathir said that most of the government owned firms are not profitable hence not contributing to the national revenue significantly. What are the reasons for the non-profitability of GLCs? These companies get full government support yet they are not adding revenue to the government (Firdaws, 2014).

Scholars have identified significant relationships between politicians and firms in Malaysia, but consideration of political connections and Shari'ah compliance have not been explored, which makes Malaysia an interesting case for research. This study will help government, regulators, investors and the general public to understand the performance of politically connected firms, Shari'ah compliant firms and politically connected Shari'ah compliant firms. Furthermore the governance issues related to agency theory and moral

Corresponding Author: Irum Saba, email: irumsaba82@gmail.com 
hazard in these firms will also be discussed which will help regulators for policy development and design. Studies show that good governance leads to profitable business. Gill (2001) found that investors in emerging markets experienced higher investment returns from companies with good governance.

Malaysia is considered a global leader and role model in the field of Islamic finance with a track record of 30 years with the development of Islamic Banking Act in 1983, now repealed by Islamic financial services act (IFSA) 2013. The strong commitment, continuous effort and steps taken by the government, Bank Negara Malaysia (BNM), Securities Commission (SC) and other related institutions are the reasons for the Islamic finance growth in Malaysia. The establishment of Shari'ah Advisory Council (SAC) in May 1997 is among the major steps taken by the BNM for Islamic finance industry and Shari'ah approved securities were listed on Kuala Lumpur stock exchange in June 1997. It is important to analyze the performance of Shari'ah compliant firms versus non-compliant firms as currently $75 \%$ of the Securities listed on Bursa Malaysia are Shari'ah compliant2.

Malaysia is an attractive case as it is a hub of Shari'ah compliant finance. Islamic finance industry in Malaysia is growing because of supported environment, continuous product innovation, diversity of financial institutions, availability of financial infrastructure and proactive regulatory system. Malaysia's economy sustained the financial shocks in last three decades; commodity shock in 1985-1986, Asian financial crisis in 1997-1998 and the global financial crisis in 2008 (Athukorala, 2010).

\section{Literature and Motivation}

The study of political connections or political patronage and their impact on the business domain is an area of interest for researchers. Political connections do help firms in terms of advantageous supervisory environment, easy access to bank loans, which in turn enhances the firms' performance. In China, political connections help firms avoid market failures (Li, Meng, Wang, \& Zhou, 2008). Faccio (2009) considered an organization to be politically connected if its top officials are a large shareholder is a member of parliament, a minister or head of state or closely related to a top officials.

Connections between politicians and business houses are not uncommon. Faccio (2006) said that firms prefer to have an association with political groups and politicians mainly to benefit from the following: preferential treatment from state owned enterprises, preferential access to credit, exemptions in taxation, and preferential treatment in competing for government contracts. Moreover, the politically connected firms also get lax regulatory oversight or stiffer regulatory oversight of its rivals, and benefits in many other forms. He considered an organization to be politically connected if its top officials or a large shareholder is a member of parliament, a minister or head of state or closely related to a top official.

In recent years, research on political connections/patronage of Malaysian firms has increased (Bliss \&Gul, 2012a; Ebrahim, Girma, Shah, \& Williams, 2014; Johansson, 2014; Mitchell \& Joseph, 2010). The political patronage of the Malaysian government influences the corporate sector through listing restrictions, direct equity ownership of listed firms, control of the banking sector, and also through government-sponsored "institutional" investors (Fraser et al. 2006). Does political patronage add value to the firms' performance or not? A number of researchers (Fisman, 2001; Goldman, Rocholl, \& So, 2006; Li et al., 2008) found that political connections have positive effect on firms' performance. Yet another group of researchers (Boubakri, Guedhami, Mishra, \&Saffar, 2012; Faccio\&Faccio, 2006; Fan, Wong, \& Zhang, 2007) found evidence of negative effects of political connections on firms' performance. A study conducted by (Wu, Wu, Zhou, \& Wu, 2012) on the Chinese state-owned enterprises and private firms for the period 1999-2007 presented mixed results regarding the effect of political connections on firms' performance. So far there is no conclusive finding or in-depth study on the performance of politically connected firms covering the horizon from 1997 till 2013. Studies done by Bliss and Gul (2012a), Chen et al. (2013), and Ebrahim et al. (2014) are very important but they focused on politically connected and non-connected firms' only. Interestingly, our study not only focuses on politically connected and non-connected firms to ascertain whether political connections add to firms' value or vice versa but also takes into account the Shari'ah compliant and non-compliant firms in the politically connected and non-connected firms and their corresponding performances during the last two financial crises. This makes our study unique, yet as an extension of earlier studies. Also, Shari'ah stance on the political connections and rent-seeking behavior needs to be studied further as research in this area is negligible. 
The recurrent financial crisis in the world has put Shari'ah compliant finance into the limelight and Islamic finance is considered as an alternative financial system when compared with conventional financial system. Academicians (Alam, 2009; Beck, Demirgüç-kunt, \&Merrouche, 2013; Hazzi, 2013) started looking into Islamic finance to see whether it is more stable than conventional financial system or not. This analysis will help in ascertaining the position of Shari'ah compliant firms with reference to political connections and non-compliant firms, i.e. whether these firms really perform better and are more stable than non-compliant firms or not. So far, the impact of political connections on firms' performance and comparison with the Shari'ah compliant firms is scantily documented globally. Malaysia is particularly suited for this study, given its leading position in Islamic finance.

Shari'ah provides clear guidance for politics, economy and financial system of Islamic economy. A Shari'ah compliant firm should not have problems of agency, moral hazards and adverse selection as these are against the Maqasid al Shari'ah. If Shari'ah compliant firms follow the Shari'ah strictly then the Shari'ah compliance should add to the firms' value and these firms should perform better than the non-compliant firms. In the current scenario, it is important to conduct research on the fundamental yet untouched links of political economy and Islamic finance. Ample research has been done on the political connections in relation to firms but a holistic research on the performance of firms' with reference to the impact of political connections and Shari'ah compliance is still scarce. The performance behavior of the firms during normal business cycles and during financial crises needs to be analyzed to know about the most stable firms during these crises.

This study will help investors, regulators, companies, government, academicians and practitioners in the future decision making to ensure better economic and firms' growth, locally and globally. The focus of this research is on comparing and contrasting the performance of politically connected and Shari'ah compliant listed firms.

Islam focuses on social justice and economic well-being of the whole society. Islam promotes the circulation of wealth so that wealth cannot be concentrated in a few hands. Shari'ah compliant business and profit is encouraged in Islam. The Holy Prophet PBUH said "be involved in business as 9 out of 10 sources of income lie in business". The Islamic economic model is based on risk and profit sharing and not on interest. Shari'ah provides comprehensive regulations for businesses and contracts. The rules ensure that parties are well informed for business decisions and activities.

The main principles of Islamic finance are as follows:

- Prohibition of interest also known as usury/riba.

- Risk sharing, where the supplier of funds becomes investor rather than creditors and shares profit in return.

- Prohibition of speculative activities to discourage gambling and hoarding.

- Sanctity of contacts, which reduce asymmetric information and moral hazard.

Shari'ah approved activities, which prohibits investment in business dealing with drugs, alcohol, pork, games of chance.

- Social justice, whereby any transaction leading to injustice and exploitation is prohibited (Mejía, Aljabrin, \& Awad, 2014).

Information asymmetry means that during transaction one party has more information/knowledge than the other party which leads to two types of problems. The ex-ante problem is adverse selection when loans/investments are made to/in a poor credit risk. The ex-post problem is of moral hazard when loaned/invested funds are misused and/or utilized in inappropriate ways. Naturally the degree of information asymmetry, and the resulting adverse selection and moral hazard problems, depends upon the amount and quality of information flows between lender or investor and borrower (Khan, 2010). Shari'ah compliant firms should perform better as compared to non-compliant firms when it comes to issues of asymmetric information because of their transparency in compliance with Shari'ah.

Malaysia, being the hub of Islamic finance, promotes companies to conform to Shari'ah requirements to successfully complete the Shari'ah screening process to be registered as Shari'ah compliant firms on Bursa Malaysia. The Shari'ah Advisory Council (SAC) reviews the Shari'ah status of the securities on an annual basis and updates the list twice a year. The SAC adopts a two-tier qualitative and quantitative approach, which includes business activities and financial ratios benchmarks in order to determine Shari'ah status of the listed 
Saba et al

securities. The securities are classified as Shari'ah-compliant if the business and financial ratio benchmarks set by SAC is met. To safeguard the investors' interests, companies have to observe strict Shari'ah requirements as prescribed by the Shari'ah Advisory Council of Bank Negara Malaysia (BNM) (Sani\& Othman, 2013) (Appendix 3 and Appendix 4).

It is said that Islamic finance is resilient to shocks due to its inherent stability (Mirakhor, 2009) and that the world of banking and finance without riba (usury) and maysir (gambling) is a better alternative to the conventional banking and finance (Siddiqi, 2006). The recurrent financial crisis put the conventional financial world (interest based) under strict scrutiny. Some scholars are trying to fix the inherent instability of the conventional finance whereas the others are looking for possible alternative financial systems, which leads them to the Islamic financial system that is apparently offering financial stability and resilience (Ibrahim \&Mirakhor, 2014). Alam (2009) analyzed the performance of Shari'ah compliant equities by constructing three portfolios on the basis of Standard \& Poor's (S\&P) Europe 350 for overall market, the market without financial firms and the market of Shari'ah compliant equities. He found that the Shari'ah compliant equities outperform the other two portfolios in all aspects of analysis. He also mentioned the role of Islamic finance in withstanding the turbulent financial crisis.

There are few recent studies on the performance comparison of Islamic banks versus non-Islamic banks which were helpful for our study to find out the stability of Islamic finance in the case of banking sector. Though our focus is on Shari'ah compliant firms but the existing literature on the Islamic banks versus conventional banks performance could be used as a stepping stone for analyzing the performance of the Shari'ah compliant listed firms.

Rosman et al. (2013) examined the efficiency level of Islamic banks during the financial crisis specifically in Middle Eastern and Asian countries from 2007 to 2010 including 79 Islamic banks across a number of countries. They found that Islamic banks were able to sustain operations through the crisis. However, the study also shows that the majority of these Islamic banks were scale inefficient. Most of the scale inefficient banks were operating at decreasing returns to scale. This study also found that both profitability and capitalization were the main determinants of Islamic banking efficiency. Hence, the findings of this study have policy implications and contribute to policy-making by providing empirical evidence on the performance of the Islamic banks and their efficiency levels.

Ahmad \& Rahman (2012) examined the relative efficiency of Islamic commercial banks and conventional commercial banks in Malaysia using Data Envelopment Analysis (DEA) for the period of 2003 to 2007. Their study found that the conventional commercial banks outperformed the Islamic commercial banks in all efficiency measures and indicated that conventional commercial banks may have been more efficient than Islamic commercial banks due to managerial efficiency and technological advancement. Gishkori\&Ullah (2013) employed DEA to investigate the technical efficiency of Islamic banks and conventional banks operating in Pakistan for the period of 2007 to 2011. The sample included Islamic, conventional and foreign banks and the study found that the technical inefficiency particularly for the Islamic banks was due to scale inefficiency instead of pure technical inefficiency. Alzalabani\& Nair (2013) did research on how Islamic banks survived the severity of financial recession, with special focus on Al Rajhi Bank in the Kingdom of Saudi Arabia. They found that financial recession impact on Islamic banks was not as severe as it was on their counterparts.

The above mentioned studies measured the performance of Islamic banks as compared to conventional banks especially during recent financial crisis but the overall performance of listed Shari'ah compliant firms from different industries which includes financial and non-financial industries by incorporating the impact of the two historical financial crisis of Malaysia is scarce.

Political patronage is not a new phenomenon. Political patronage refers to the use of political powers by leaders to grant economic favors to connected firms. There are four essential factors which motivate businesses to have political patronage: social networking, information view, image building and gratification (rent-seeking) (Lim, Chai, Zhao, \& Lim, 2012). One of the earlier studies conducted by Krueger (1974) found that firms in India and Turkey spend resources on rent seeking in an attempt to get preferential benefits in competition. 
Fisman (2001) studied the valuation of rents for Indonesian firms during the period of 1995-1998, using stock market and accounting data of stocks traded on the Jakarta Stock Exchange (JSX), data on the group affiliations of all JSX firms, political dependence of a subset of these firms and a series of events related to the condition of Suharto's health, and found that political connections played an important role in the Indonesian economy.

Faccio (2006) studied corporate political connections in a larger sample of 20,202 publically traded firms in 47 countries, using variables of political connections, regulatory environment (regulations that limit the business activities of public officials), corruption, quality of legal environment, openness and democracy, freedom of press, education and economic development. He found that in 35 out of 47 countries, there are firms with political connections particularly in countries with less stringent regulations of political conflict of interests, high corruption and strong foreign investment barriers. His results were in line with the results of Fisman (2001).

Lot of is research has been done in China on political connections and firms' performance. For example, Li et al. (2008) studied the role of affiliation of private enterprises in China with the ruling Communist party using the survey method. They used firm's profitability, party membership, firm's attributes, owner's human capital and owner's political variables. They found that party membership has positive effect on the performance of private firms when human capital and other variables were kept constant. They also found that party membership assisted in firms' access to loans and increased the firms' confidence in the legal system. They concluded that political connections are more important to firms' performance in countries where legal protection and market institutions are weak. Lim et al (2012) focused on the impact of political patronage on the capital structure of companies listed on the Shanghai Stock Exchange. In congruence with $\mathrm{Li}$ et al.'s (2008) findings, the researchers found positive and significant linkage between leverage and political patronage. They also found an indirect link between political patronage and capital structure based on the size of the firms, growth of firms (change of total assets), earnings volatility (standard deviation of return on assets) and their profitability (earnings before interest and tax divided by total assets). Wu et al. (2012) investigated the effect of political connections on the performance of state-owned enterprises (SOEs) and private sector enterprises in China over the period 1999 to 2007 and found that private firms having politically-connected managers outperformed those having managers without political connections, whereas local SOEs with politically connected managers under-performed compared to those without such managers. They also found that private enterprises with political connections enjoyed more tax benefits, while local SOEs with politically connected managers were prone to severe over-investment problems.

In the Malaysian context, Gomez and Jomo (1997) examined Malaysia's political economy and authored a comprehensive book on it. Their work is significantly important to understand Malaysia's history, political system and policies. They cited that most of political parties in Malaysia are ethnically formed. Barisan National (BN) has long been the only multi-ethnic and multi-party coalition. BN is coalition of 13 political parties but dominated by the United Malay National Organization (UMNO), Malaysian Chinese Association (MCA) and the Malaysian Indian Congress (MIC). Since 1955, UMNO enjoyed the long-term incumbency and victory in elections. The implementation of New Economic Policy (NEP) since 1970 reduced poverty considerably but led to growth of ethnic issues, influence of political patronage in the business sector, increase in corruption, rent-seeking behaviour and abuse of power. In our research, we used the work done by Gomez and Jomo (1997) for the identification of informally politically connected firms.

Another important study focusing Malaysia was done by Fraser, Zhang, and Derashid (2006) and they examined the political patronage and capital structure of the firms in Malaysia over a period of 10 years and found an important and positive link between leverage and the three measures of political patronage. 3 They also found an indirect connection between the capital structure of the firms and political patronage based on firm size and profitability. Politically connected firms tend to have higher leverage and are larger in sizes in terms of total assets. Hence, leverage, firm size and tangibility are included in our study as well.

Mitchell and Joseph (2010) studied the impact of capital controls, leadership and political connections in Malaysia starting from the imposition of capital controls till 2000 by analyzing 625 firms listed on the KLSE main board. They found that financial firms with political connections

The three proxies used by Fraser et al. are;

1. Percentage of direct government equity ownership of a firm, 
2. Percentages of equity owned by "institutional" investors as institutional investors in Malaysia are either controlled by government or by government sponsored Bumiputra agencies.

3. The informal ties a firm may have with powerful politicians in Malaysia.

These have not performed as well as other firms, because the capital controls were imposed, but the results of the political connections were not as strong as that in the study of Johnson and Mitton (2003). Their study shows that firms behaved in the same way during the Mahathir and the Badawi period. The important variables they used in the study were ROA (profitability measure), debt ratio (total debt/total assets), firms' growth (\% increase in total assets) and firm size (natural log of total assets). We used some of the variables taken by the Mitchell and Joseph (2010) in their study.

Bliss and Gul (2012a) investigated the relationship between political connection and the cost of debt for Malaysia's top 500 non-financial public listed companies, in terms of market capitalization, for the years 2001-2004. They found that politically connected firms have higher leverage, higher likelihood of reporting a loss, higher likelihood of having negative equity and higher likelihood of being audited by big audit firms. They also found that CEO duality (where chief executive officer of the firm and the chairman of the board are same person) present in politically connected firms was perceived negatively by the lenders, although the presence of higher numbers of independent directors on the audit committee could mitigate this perceived risk. Motivated by the study of Fraser, Zhang, and Derashid (2006), Bliss and Gul (2012b) focused on the political connections and leverage of Malaysian firms. They found that $12 \%$ of the politically connected firms which are positively associated with leverage have negative equity and market-to-book ratio. They also found that politically connected firms have significantly lower returns on assets when compared to firms without political connections.

Chen et al. (2013) studied the effect of political events on share prices of the listed firms linked to government in power compared to firms with no political networks in the case of Malaysia from 1999-2000. They found that firms associated with government rises $4 \%$ in share price comparative to unconnected firms when identical political events happen. The higher value of politically connected firms is due to the privileged treatments and access to state benefits. This research is very close to our topic of research but our research not only have enhanced time frame and more explanatory variables but also incorporating the Shari'ah compliance firms' performance comparison with non-compliant firms, the politically connected firms and non-politically connected firms.

Johansson (2014) studied the impact of Malaysia's 2008 elections, as the election results were quite surprising and challenging to the competitive authoritarian regime, directly impacting firms with ties to the ruling coalition. He found that, indeed, firms with political patronage were adversely affected by the 2008 election outcomes. Specifically, the firms with close links to BN experienced a negative value effect and a decrease in their leverage level more than other firms after the 2008 election, showing that their access to debt capital had become more restricted.

Ebrahim et al. (2014) studied the impact of political patronage on 751 Malaysian firms' capital structure for the period 1998-2009. Their study shows that the firms set leverage targets and adjust them with deviations at the rate of $28 \%$ per annum. They also found significant difference in the capital structure of patronised firms relative to independent firms following the exogenous shocks during the crisis period 1998-2001. After 2002 the capital structures of patronised and independent firms were statistically equivalent.

The literature review shows that firms tend to have political connections for the ease of their business conduct. Politically-connected firms try to get benefits related to tax payment on the basis of the support of the political personalities. This leads to several issues of agency problem, information asymmetries and moral hazards. Government companies are normally headed by politically connected individuals. The literature also shows that firms with political connections perform well in some cases and conversely in other cases. But it is yet to be ascertained that politically connected firms do perform better than the non-politically connected firms or vice versa.

\section{Theoretical Framework}

Politics and economics are two crucial blocks of every country. Businesses knit close ties with politicians for the benefit of their businesses. Islam appreciates cooperation for good deeds and wellness of the society but forbid unjust acts that may harm people or society as mentioned in the Qur'an: "And cooperate in 
righteousness and piety, but do not cooperate in sin and aggression. And fear Allah; indeed, Allah is severe in penalty" (5:2). Islam emphasizes the importance of trade and business. But the business should be conducted as prescribed by Shari'ah in order to achieve Maqasid al Shari'ah which is the basis of all human activities. Maqasid is an Arabic word which means purpose or objective. Shari'ah is defined as Islamic Law which sets a system of ethics and values that covers all parts of life including personal, social, political, economic and intellectual dimensions of human beings which cannot be separated from Islam's basic beliefs, values and objectives. Shari'ah compliant firms need to uphold the essence of Maqasid al Shari'ah in their business conduct and embrace the value of God-consciousness (Taqwa) in every situation. With this consciousness, every member of a firm should perform its roles and responsibilities as the vicegerent of God.

A firm's main objective is to maximize profit and or minimize cost. Firms try to minimize risks associated with operations and financial decisions. Achieving bigger market share with strong presence in the industry is also one of the important goals for some firms. All this raises an important question: Can Shari'ah compliance and political connections help firms to maximize profits, minimize costs and risks and hence add to firms' value or vice versa? Firms connect to politicians to get maximum benefit by having easy access to loans, reduction in taxes and various other benefits, for enhancing profits and reducing costs. Shari'ah based firms work on the basis of profit and loss sharing. According to the rules of Shari'ah, a Shari'ah-compliant firm cannot indulge in activities or transactions related to gambling, interest, speculation and other non-halal activities. Perhaps Shari'ah compliant firms earn less profit as compared to non-compliant firms but then Shari'ah compliant firms should be contented as they conduct their businesses in line with the principles of Shari'ah and take care of society as large to fulfill their social responsibilities. For example, non-compliant firms might externalize pollution costs, whereas Shari'ah compliant firms should internalize such cost as part of their social responsibilities in accordance the Maqasid al Shari'ah.

According to Arsad et al. (2014) Corporate Social Responsibility (CSR) mainly covers three key areas namely: environmental performance, economic performance and social performance. Environmental issues include the impact of production processes, products and services on air, land, biodiversity and human health. Economic performance covers wages and benefits, productivity, job creation, outsourcing expenditures, research and development investments, and investments in training and other forms of human capital. Social performance includes traditional topics such as health and safety, employee satisfaction and corporate philanthropy, as well as more external topics such as labour and human rights, diversity of the workforce and supplier relations. Therefore, any firm that claims to be Shari'ah-compliant should practice best corporate social responsibility practices as it is clearly defined that Shari'ah compliant firms should take care of all stakeholders and society at large.

A firm being Shari'ah compliant and politically connected has different dilemmas when it comes to financial decisions. Shari'ah compliant firms need to be in line with best practices of Islamic finance. Politically connected firms tend to go beyond their means in order to get financial benefits which leads to principalagent conflicts. The management of a firm is the agent (wakeel) of shareholders. One of the important financial theories related to this study is of agency theory which is concerned with resolving problems that can exist in agency relationships between shareholders and company's executives. In the financial world, the two most important agency relationships are those between stockholders and managers, and stockholders and creditors. The synchronized decision between principal and agent for the better performance of the company is very important.

Trade-off theory focuses on the impact of other external factors on neutralizing the benefits of the use of debt and suggests an optimal capital structure to trade-off between benefits and costs involved in using debt capital. The politically connected firms and non-connected firms tend to have different levels of debt. The Shari'ah compliant firms already have the limitation for the usage of debt. These firms have lower debt ratio in order to remain compliant with Shari'ah whereas the politically connected firms' tend to higher leverage. Jensen and Meckling (1976) pointed out the agency cost involved in the conflict of interest between the managers and the shareholders, which leads to finance investment opportunities through outside fund. The agency cost of outside equity, agency cost of debt and agency cost of principal and agent are crucial problems of the firms. Theoretically speaking, Shari'ah compliant firms should have more transparency and less agency problems as man is a Khalifa of Allah SWT. Shari'ah compliant firms abide by the rules prescribed by Shari'ah, and, hence, tend to have more transparency in the firms' operations and should make better decisions for the 


\section{Saba et al}

Our study focuses on the performance analysis of politically connected firms and Shari'ah compliant firms listed on bursa Malaysia. This study will help understand to what extent Shari'ah compliance and political connections add to firms' performance in terms of profitability by using return on assets and return on equity as proxy.

\section{Research Methodology and Data}

The objective of the study is:

To analyze and compare the performance of listed politically connected firms and Shari'ah compliant firms.

Hypothesis 1: Political connections add to good firm performance.

Hypothesis 2: Shari'ah compliance adds to good firm performance.

Earlier studies showed that political connections provide benefits to firms in the shape of loan availability, taxation, lax regulations and etc. In this case companies with political connections should have performed better as compared to other firms. On the other hand firms complying with Shari'ah follow the Shari'ah rules strictly which should lead the companies to the better performance and less governance issues.

The research questions of the study are as follows:

1. Do political connections contribute to good firm performance?

2. Does Shari'ah compliance contributes to good firm performance?

Firm's performance is measured by its profitability. The proxies used for the profitability are return on assets and return on equity.

Profitability it $=\alpha+\beta 1$ Political Connection it $+\beta 2$ Shari'ah Compliance it $+\beta 3$ Financial Crisis $+\beta 4$ Firm Size it + $\beta 5$ Tangibility it $+\beta 6$ Leverage it $+\beta 7$ GDP it $+\beta 8$ Interest Rate it $+\beta$ Inflation Rateit $+\varepsilon$ it

Political connection $=$ Dummy is 1 for politically connected firms, and 0 otherwise

Shari'ah Compliance $=$ Dummy is 1 for Shari'ah compliance, and 0 otherwise

Financial Crisis $=$ Dummy is 1 for financial crisis, and 0 otherwise

Profitability = Return on Equity (ROE) and Return on Assets (ROA)

Size of the firm = Natural logarithm of total assets

Tangibility $=$ Fixed assets divided by total assets

Leverage $=$ Total debt divided by total assets

Stock prices of the firms

Macro-Economic Variables:

The main focus of the model is to look at political connections and compliance on firms' performance by controlling firms' specific characteristics and macroeconomic variables.

The macroeconomic variables are added in order to analyze the sensitivity to change in macroeconomic factors. Firms' performance gets the impact of the country's economic conditions, especially in the case of emerging markets. Gross Domestic Product (GDP) indicates economic growth and inflation rate plays a significant role in the economic growth of the country. Higher interest rate makes borrowing expensive and hence impacts the firms' performance.

Gross Domestic Product (GDP) = GDP per capita

Interest rate $=$ Base Lending Rate (BLR) of banks is used as proxy for interest rates

Inflation rate $=$ Change in consumer price index is used as a proxy for inflation rates

The following three criteria are used for identification of the politically connected firm:

1) Firms' having unofficial political connections as identified by Gomez and Jomo (1997), Johnson 
2) Khazanah managed firms

and Mitton (2003) and Faccio (2006)

3) GLCs

In this study empirical analysis is based on the ordinary least squares (OLS) regressions for all of the equations by controlling for year. The OLS regression method is used in this paper to find out the relationship between political connections, Shari'ah compliance and performance of firms. Earlier studies related to political connections and firm performance have used OLS widely (Bliss \&Gul, 2012a, 2012b; Chen et al., 2013; Faccio, 2007; Li et al., 2008; Mitchell \& Joseph, 2010; Muttakin, Monem, Khan, \&Subramaniam, 2015; Wu et al., 2012).

Data is collected from DataStream, Malaysian government reports, Bursa Malaysia, KhazanahNasionalBerhad (investment holding vehicle of Malaysian government) and firms' financial reports. For the analysis annual financial data for the period 2000-2014 is used. The total of 941 listed firms is used for this study. Out of 941 listed companies, 634 companies are Shari'ah compliant and remaining are non-compliant firms. The politically connected firms used in our study are 118 out of 941 listed companies.

Different variables are used for analyzing the performance of firms. In our study we have used return on assets and return on equity as proxy for profitability and to measure firm performance as per the literature. Leverage, tangibility and size of the firm are the firm specific variables used in this study. Leverage is used to measure the level of debt used by the firms. Size is the natural logarithm of total assets. Tangibility is the ratio of fixed assets to total assets of the firms (Li et al., 2008; Mitchell \& Joseph, 2010; Muttakin, Monem, Khan, \&Subramaniam, 2015; Wu et al., 2012).

Table 1: Summary Statistics of Full Sample

\begin{tabular}{|l|c|c|c|c|c|}
\hline Variables & Observations & Mean & Standard Deviation & Min & Max \\
\hline ROA & 10631 & 5.67496 & 0.0764149 & -0.3285 & 6.96551 \\
ROE & 10382 & 10.3731 & 0.0456972 & 5.75384 & 10.4299 \\
Size & 10631 & 12.6929 & 1.662585 & 5.79301 & 20.277 \\
Tangibility & 10571 & 3.20516 & 1.182725 & -8.3471 & 4.60517 \\
Leverage & 9462 & 2.59077 & 1.499593 & -4.6052 & 8.28361 \\
GDP & 10631 & 1.37617 & 1.879877 & -5.0648 & 2.33977 \\
Inflation & 10631 & 0.70866 & 0.5503599 & -0.539 & 1.69392 \\
Interest Rate & 10631 & 5.64393 & 0.8561579 & 4.6 & 7.67333 \\
\hline
\end{tabular}

Table 2: Summary Statistics of Shari'ah Compliant Firms

\begin{tabular}{|l|c|l|c|l|l|}
\hline Variables & Observations & Mean & Standard Deviation & Min & Max \\
\hline ROA & 7477 & 5.68 & 0.05 & 4.68 & 6.97 \\
ROE & 7347 & 10.37 & 0.00 & 10.31 & 10.43 \\
Size & 7477 & 12.53 & 1.47 & 8.06 & 18.52 \\
Tangibility & 7452 & 3.34 & 0.97 & -5.68 & 4.61 \\
Leverage & 6795 & 2.51 & 1.46 & -4.61 & 7.75 \\
GDP & 7477 & 1.37 & 1.9 & -5.06 & 2.34 \\
Inflation & 7477 & 0.71 & 0.55 & -0.54 & 1.69 \\
Interest Rate & 7477 & 5.63 & 0.85 & 4.6 & 7.67 \\
\hline
\end{tabular}


Saba et al

Table 3: Summary Statistics of Non- Shari'ah Compliant Firms

\begin{tabular}{|l|c|l|c|c|c|}
\hline Variables & Observations & Mean & Standard Deviation & Min & Max \\
\hline ROA & 3154 & 5.67 & 0.12 & -0.33 & 6.22 \\
ROE & 3035 & 10.37 & 0.08 & 5.75 & 10.39 \\
Size & 3154 & 13.08 & 2 & 5.79 & 20.28 \\
Tangibility & 3119 & 2.87 & 1.52 & -8.35 & 4.61 \\
Leverage & 2667 & 2.8 & 1.58 & -4.61 & 8.28 \\
GDP & 3154 & 1.4 & 1.84 & -5.06 & 2.34 \\
Inflation & 3154 & 0.7 & 0.54 & -0.54 & 1.69 \\
Interest Rate & 3154 & 5.67 & 0.88 & 4.6 & 7.67 \\
\hline
\end{tabular}

ROE in Shari'ah compliant firms is lower than the non-compliant firms.

The table 4 and table 5 provide the descriptive statistics of politically connected and non-connected firms in the sample. The descriptive statistics shows that the politically connected firms mean leverage is higher than the non-connected firms. The mean ROA of politically connected firms is very slightly higher than the non-connected firms.

Table 4: Summary Statistics of Politically Connected Firms

\begin{tabular}{|l|c|l|c|l|l|}
\hline Variables & Observations & Mean & Standard Deviation & Min & Max \\
\hline ROA & 1517 & 5.68 & 0.04 & 5.28 & 6.11 \\
ROE & 1463 & 10.37 & 0.01 & 9.86 & 10.4 \\
Size & 1517 & 14.65 & 1.91 & 9.42 & 20.28 \\
Tangibility & 1513 & 3 & 1.48 & -2.33 & 4.61 \\
Leverage & 1407 & 2.8 & 1.38 & -4.61 & 6.42 \\
GDP & 1517 & 1.42 & 1.8 & -5.06 & 2.34 \\
Inflation & 1517 & 0.68 & 0.54 & -0.54 & 1.69 \\
Interest Rate & 1517 & 5.8 & 0.92 & 4.6 & 7.67 \\
\hline
\end{tabular}

Table 5: Summary Statistics of Non- connected Firms

\begin{tabular}{|l|c|c|c|c|c|}
\hline Variables & Observations & Mean & Standard Deviation & Min & Max \\
\hline ROA & 9114 & 5.67 & 0.08 & -0.33 & 6.97 \\
ROE & 8919 & 10.37 & 0.05 & 5.75 & 10.43 \\
Size & 9114 & 12.37 & 1.37 & 5.79 & 20.01 \\
Tangibility & 9058 & 3.24 & 1.12 & -8.35 & 4.61 \\
Leverage & 8055 & 2.55 & 1.52 & -4.61 & 8.28 \\
GDP & 9114 & 1.37 & 1.89 & -5.06 & 2.34 \\
Inflation & 9114 & 0.71 & 0.55 & -0.54 & 1.69 \\
Interest Rate & 9114 & 5.62 & 0.84 & 4.6 & 7.67 \\
\hline
\end{tabular}


COMSATS Journal of Islamic Finance

Table 6: OLS regressions examining the impacts of Shari ah Compliance and Political Connections on the firms' performance

\begin{tabular}{|c|c|c|c|c|c|c|}
\hline \multicolumn{4}{|c|}{ ROA } & \multicolumn{3}{|c|}{ ROE } \\
\hline & Model 1 & Model 2 & Model 3 & Model 4 & Model 5 & Model 6 \\
\hline SC & $\begin{array}{c}0.00963^{* * *} \\
(5.38)\end{array}$ & $\begin{array}{c}0.00956^{* * *} \\
(5-35)\end{array}$ & $\begin{array}{l}0.00883^{* * *} \\
\quad(4.55)\end{array}$ & $\begin{array}{l}0.00268^{* *} \\
(2.29)\end{array}$ & $\begin{array}{l}0.00269^{* *} \\
(2.30)\end{array}$ & $\begin{array}{l}0.00274^{* *} \\
(2.16)\end{array}$ \\
\hline PC & $\begin{array}{c}-0.0119^{* * *} \\
(-4.68)\end{array}$ & $\begin{array}{c}-0.0119^{* * *} \\
(-4.70)\end{array}$ & $\begin{array}{c}-0.0149^{* * *} \\
(-3.73)\end{array}$ & $\begin{array}{c}-0.00157 \\
(-0.93)\end{array}$ & $\begin{array}{c}-0.00155 \\
(-0.92)\end{array}$ & $\begin{array}{c}-0.00135 \\
(-0.51)\end{array}$ \\
\hline Size & $\begin{array}{c}0.00729^{* * *} \\
(13.01)\end{array}$ & $\begin{array}{c}0.00728^{* * *} \\
(12.99)\end{array}$ & $\begin{array}{c}0.00732^{* * *} \\
(13.03)\end{array}$ & $\begin{array}{l}0.00101^{* * *} \\
(2.72)\end{array}$ & $\begin{array}{l}0.00101^{* * *} \\
(2.74)\end{array}$ & $\begin{array}{l}0.00101^{* * *} \\
(2.71)\end{array}$ \\
\hline Tangibility & $\begin{array}{c}0.000377 \\
(0.52)\end{array}$ & $\begin{array}{c}0.000454 \\
(0.62)\end{array}$ & $\begin{array}{c}0.000360 \\
(0.49)\end{array}$ & $\begin{array}{c}-0.000318 \\
(-0.67)\end{array}$ & $\begin{array}{c}-0.000333 \\
(-0.70)\end{array}$ & $\begin{array}{c}-0.000327 \\
(-0.68)\end{array}$ \\
\hline Leverage & $\begin{array}{c}-0.00622^{* * *} \\
(-11.54)\end{array}$ & $\begin{array}{c}-0.00624^{* * *} \\
(-11-58)\end{array}$ & $\begin{array}{c}-0.00624^{* * *} \\
(-11.58)\end{array}$ & $\begin{array}{c}-0.000935^{* * *} \\
(-2.62)\end{array}$ & $\begin{array}{c}-0.000931^{* * *} \\
(-2.61)\end{array}$ & $\begin{array}{c}-0.000931^{* * *} \\
(-2.61)\end{array}$ \\
\hline Inflation & & $\begin{array}{c}-0.000602 \\
(-0.26)\end{array}$ & $\begin{array}{c}-0.000604 \\
(-0.27)\end{array}$ & & $\begin{array}{c}0.000955 \\
(0.64)\end{array}$ & $\begin{array}{c}0.000954 \\
(0.64)\end{array}$ \\
\hline Interest Rate & & $\begin{array}{c}0.00717^{* *} \\
(2.38)\end{array}$ & $\begin{array}{c}0.00715^{* *} \\
(2.38)\end{array}$ & & $\begin{array}{c}-0.00191 \\
(-0.97)\end{array}$ & $\begin{array}{c}-0.00190 \\
(-0.97)\end{array}$ \\
\hline GDP & & $\begin{array}{c}-0.000233 \\
(-0.41)\end{array}$ & $\begin{array}{c}-0.000229 \\
(-0.41)\end{array}$ & & $\begin{array}{l}0.00000470 \\
(0.01)\end{array}$ & $\begin{array}{l}0.00000457 \\
\quad(0.01)\end{array}$ \\
\hline SCPC & & & $\begin{array}{c}0.00447 \\
(0.96)\end{array}$ & & & $\begin{array}{c}-0.000292 \\
(-0.10)\end{array}$ \\
\hline Year & $\begin{array}{c}0.000356^{*} \\
(1.82)\end{array}$ & $\begin{array}{c}0.00177^{* * *} \\
(2.70)\end{array}$ & $\begin{array}{c}0.00176^{* \star *} \\
(2.68)\end{array}$ & $\begin{array}{l}0.000216^{*} \\
(1.69)\end{array}$ & $\begin{array}{c}-0.000184 \\
(-0.43)\end{array}$ & $\begin{array}{c}-0.000183 \\
(-0.43)\end{array}$ \\
\hline Constant & $\begin{array}{c}4875^{* * *} \\
(12.42) \\
\end{array}$ & $\begin{array}{l}1.987 \\
(1.49) \\
\end{array}$ & $\begin{array}{l}2.011 \\
(1.50) \\
\end{array}$ & $\begin{array}{c}9928^{* * *} \\
(38.83) \\
\end{array}$ & $\begin{array}{c}1074^{* * *} \\
(12.34) \\
\end{array}$ & $\begin{array}{c}10 ! 74^{* * *} \\
(12.34) \\
\end{array}$ \\
\hline Adjusted R2 & 0.310 & 0.314 & 0.314 & 0.175 & 0.154 & 0.144 \\
\hline Observations & 9423 & 9423 & 9423 & 9197 & 9197 & 9197 \\
\hline Model p_value & 0.0000 & 0.0000 & 0.0000 & 0.0011 & 0.0057 & 0.0100 \\
\hline
\end{tabular}

Notes: The table represents regression results of full sample of firms with dependent variable ROA and ROE. The independent firm specific variables namely Size $=\log$ of Total Assets, Leverage $=($ Total debtTotal assets $)$ and Tangibility $=$ (Property plants \& equipment) (Total assets) . Dummies for Shariah compliant firms and politically connected firms are used. SC stands for Shari'ah compliant firms, PC stands for political connected firms and SCPC stands for Shari'ah compliant politically connected firms. SCPC is interactive term Figures in parentheses are t-statistics. *** and ${ }^{* * *}$ indicate the coefficient significant at the $10 \%, 5 \%$ and $1 \%$ levels, respectively.

Table 6 shows the regression results of firms using ROA and ROE as dependent variable. The results are consistent for ROA and ROE in the case of Shari'ah compliant firms starting from model till model 6. Shari'ah compliance has positive and significant impact on the return on assets and return on equity of the firm in all 6 models as stated below. The impact of political connections on firm performance is significant but negative in the case of ROA in all models. In the case of ROE the political connections are not significant in all models starting from model 4 till model 6.

Size is significant and has positive impact on the ROA and ROE. Higher the size of the firm, higher will be the profits. The leverage is also significant in all models and has negative impact on the performance of the firms, which is in line with the theoretical framework. Tangibility is not significant in any of the model. Among the macroeconomic variables used in the model 2, model 3, model 5 and model 6 , only interest rate is significant in model 2 and model 3. Which means that interest rate has positive impact on the ROA and insignificant in the case of ROE. SCPC is the interactive term used to analyze the impact of Shari'ah compliant and politically connected firm on the performance of the firm. SCPC is insignificant in all the models of the regressions. 
Saba et al

Finally the results shows that

- Political connections do impact the firm's performance and the impact is negative.

- Shari'ah compliance adds positively to firms' performance as firms perform transactions according to Shari'ah and avoid non-permissible activities.

- Firms without political connections are likely to underperform, compared to the politically connected firms especially during the financial crises. Because politically connected firms can access the loans during credit crunch on the basis of their connections. Whereas the non-connected firms encounter problems for the funding during crises.

- Shari'ah compliant firms outperformed the non-Shari'ah compliant firms. Because the implementation of the requirements of Shari'ah on the firms' keep the firms away from ambiguous business and transactions, which in return will keep the Shari'ah compliant in better form as compared to non-compliant firms. Non-compliant firms indulge their business in the prohibited sector. Shari'ah compliant firms' should fulfill social responsibilities in better way as compared to non-compliant firms because according to Maqasid al Shari'ah, firms are supposed to take care of not only their shareholders but also society at large.

- Theoretically speaking politically connected Shari'ah compliant firms should outperform the other firms in sample. Because these firms have dual advantage; political connections will help in order to get business and support from regulator and government and at the same time Shari'ah compliance will help the company to have less debt and more asset backed business in the halal way. But the interactive term used in the regression shows that the Shari'ah compliant politically connected firm has no impact on the performance of the firm and the result is similar in all the models of the study.

\section{Conclusion}

The Shari'ah compliant firms' outperformed the politically connected and non-Shari'ah compliant firms because of the compliance with the requirement to Shari'ah. This study contributes to the existing literature in the following ways:

- The identification of the impact of the political connections and Shari'ah compliance on the listed firms' performance in the case of Malaysia.

- This study clarified that whether or not Shari'ah compliance adds value to the firms and their performance.

The results of the study help the investors to take better investment decisions, i.e. whether to invest in Shari'ah compliant firms or in non-compliant firms as the results shows that compliant firms perform better than non-compliant. For further analysis it is suggested that the different estimation techniques should be used and the full sample of firms should be distributed into different samples namely, Shari'ah compliant firms, non-compliant firms, politically connected firms, non- connected firms, compliant politically connected firms, Shari'ah compliant non-connected firms, non-compliant non-connected firms and noncompliant connected firms to evaluate the in-depth understanding of the performance of firms in all the samples.

\section{References}

Ahmad, S., \& Rahman, A. R. A. (2012). The efficiency of Islamic and conventional commercial banks in Malaysia. http://doi.org/10.1108/17538391211255223

Alam, N. (2009). Resilience of Islamic Finance During Credit Crunch - Empirical Evidence from European Market, 1-15.

Alzalabani, A., \& Nair, R. D. (2013). Financial Recession, Credit Crunch and Islamic Banks: A Case Study of Al Rajhi Bank in the Kingdom of Saudi Arabia, XVI(1), 15-36.

Arsad, S., Said, R., Yusoff, H., Haji-othman, Y., \& Ahmad, R. (2014). The Relationship between Islamic Corporate Social Responsibility and Firm 's Performance : Empirical Evidence from Shari ' ah Compliant Companies, 6(36), $161-174$.

Athukorala, P. (2010). Malaysian Economy in Three Crises.

Beck, T., Demirgüç-kunt, A., \&Merrouche, O. (2013). Islamic vs .conventional banking : Business model, efficiency and stability. Journal of Banking and Finance, 37(2), 433-447. http://doi.org/10.1016/j.jbankfin.2012.09.016

Bliss, M. a., \&Gul, F. a. (2012a). Political connection and cost of debt: Some Malaysian evidence. Journal of Banking E Finance, 
36(5), 1520-1527. http://doi.org/10.1016/j.jbankfin.2011.12.011

Bliss, M. a., \&Gul, F. a. (2012b). Political connection and leverage: Some Malaysian evidence. Journal of Banking E Finance, 36(8), 2344-2350. http://doi.org/10.1016/j.jbankfin.2012.04.012

Boubakri, N., Guedhami, O., Mishra, D., \&Saffar, W. (2012). Political connections and the cost of equity capital. Journal of Corporate Finance, 18(3), 541-559. http://doi.org/10.1016/j.jcorpfin.2012.02.005

Chen, C., Ariff, M., Hassan, T., \&Mohamad, S. (2013). Does a firm's political connection to government have economic value? Journal of the Asia Pacific Economy, 18(3), 477-501. http://doi.org/10.1080/13547860.2012.742674

Ebrahim, M. S., Girma, S., Shah, M. E., \& Williams, J. (2014). Dynamic capital structure and political patronage: The case of Malaysia. International Review of Financial Analysis, 31, 117-128. http://doi.org/10.1016/j.irfa.2013.11.004

Faccio, M. (2007). The Characteristics of Politically Connected Firms The Characteristics of Politically Connected Firms.

Faccio, M., \&Faccio, B. M. (2006). Politically Connected Firms. American Economic Review, 96(1), 369-386. http://doi.org/10.1257/000282806776157704

Fan, J., Wong, T., \& Zhang, T. (2007). Politically connected CEOs, corporate governance, and Post-IPO performance of China's newly partially privatized firms 汸. Journal of Financial Economics, 84(2), 330-357. http://doi.org/10.1016/j.jfineco.2006.03.008 Firdaws, N. (2014). Government linked companies don't contribute much to revenue. Retrieved from http://www.therakyatpost.com/news/2014/12/01/government-linked-companies-dont-contribute-much-revenue/

Fisman, R. (2001). Estimating the Value of Political Connections, 91(4), 1095-1102.

Fraser, D. R., Zhang, H., \&Derashid, C. (2006). Capital structure and political patronage: The case of Malaysia. Journal of Banking E Finance, 30(4), 1291-1308. http://doi.org/10.1016/j.jbankfin.2005.05.008

Gill, A. (2001). Corporate governance in emerging markets, (603).

Gishkori, M. A., \&Ullah, N. (2013). Technical Efficiency of Islamic and Commercial Banks : Evidence from Pakistan Using DEA Model (2007-2011), 7(4), 68-76.

Goldman, E., Rocholl, J., \& So, J. (2006). Do Politically Connected Boards Affect Firm Value?, (December).

Hazzi, O. A. (2013). The Financial Performance Analysis of Islamic and Traditional Banks : Evidence from Malaysia, 1989(57). Ibrahim, M. H., \&Mirakhor, A. (2014). Islamic finance: An overview. Pacific-Basin Finance Journal. http://doi.org/10.1016/j.pacfin.2014.02.002

Johansson, A. C. (2014). On the Challenge to Competitive Authoritarianism and Political Patronage in Malaysia. Retrieved from http://swopec.hhs.se/hascer/papers/hascer2014-029.pdf

Khan, F. (2010). Journal of Economic Behavior \& Organization How " Islamic " is Islamic Banking ?, 76, 805-820. http://doi.org/10.1016/j.jebo.2010.09.015

Krueger, A. O. (1974). The Political Economy of the Rent-Seeking Society. American Economic Review, 64, $291-303$.

Li, H., Meng, L., Wang, Q., \& Zhou, L.-A. (2008). Political connections, financing and firm performance: Evidence from Chinese private firms. Journal of Development Economics, 87(2), 283-299. http://doi.org/1 0.1016/j.jdeveco.2007.03.001

Lim, T. C., Chai, R., Zhao, D., \& Lim, X. Y. (2012). Capital Structure and Political Patronage: Evidence from China. American Journal of Business and Management, 1(4), 177-182.

Mejía, A. L., Aljabrin, S., \&Awad, R. (2014). Regulation and Supervision of Islamic Banks.

Mirakhor, D. A. (2009). The Recent Crisis: Lessons for Islamic Finance.

Mitchell, H., \& Joseph, S. (2010). Changes in Malaysia: Capital controls, prime ministers and political connections. PacificBasin Finance Journal, 18(5), 460-476. http://doi.org/10.1016/j.pacfin.2010.05.002

Muttakin, M. B., Monem, R. M., Khan, A., \&Subramaniam, N. (2015). Family firms, firm performance and political connections: Evidence from Bangladesh. Journal of Contemporary Accounting E Economics, 11(3), 215-230. http://doi.org/10.1016/j.jcae.2015.09.001

Putrajaya Committee. (2014). GLC TrasformationProgramme Progress Review 2014.

Rosman, R., Wahab, N. A., \&Zainol, Z. (2013). Efficiency of Islamic banks during the financial crisis: An analysis of Middle Eastern and Asian countries. Pacific-Basin Finance Journal. http://doi.org/10.1016/j.pacfin.2013.11.001

Sani, N. A., \& Othman, P. D. R. (2013). Revision of Shari ' ah screening methodology : the status of shari ' ah, (June), 51-63.

Siddiqi, M. N. (2006). Islamic banking and finance in theory and practice : a survey of state of the art, 13(2).

Wu, W., Wu, C., Zhou, C., \& Wu, J. (2012). Political connections, tax benefits and firm performance: Evidence from China. Journal of Accounting and Public Policy, 31(3), 277-300. http://doi.org/10.1016/j.jaccpubpol.2011.10.005 